\title{
LAPAROSCOPIC TOTALLY EXTRAPERITONEAL (TEP) HERNIOPLASTY USING TWO TROCARS: ANATOMICAL LANDMARKS AND SURGICAL TECHNIQUE
}

Hernioplastia laparoscópica totalmente extraperitoneal (TEP) utilizando dois trocárteres: reparos anatômicos e técnica cirúrgica

\author{
Leandro Ryuchi IUAMOTO'${ }^{1}$, Juliana Mika KATO${ }^{1}$, Alberto MEYER $^{2}$, Pierre BLANC ${ }^{3}$
}

From ${ }^{1}$ Faculdade de Medicina da Universidade de São Paulo (University of São Paulo Medical School), São Paulo, Brazil ${ }^{2}$ Abdominal Wall Repair Center, Samaritano Hospital, São Paulo, Brazil and ${ }^{3}$ Department of Digestive Surgery, Clinique Chirurgicale Mutualiste, Saint-Étienne, France.

HEADINGS - Laparoscopic surgery. Inguinal hernia. Surgical mesh. Surgical technique.
ABSTRACT - Background: Among endoscopic hernioplasties, totally extraperitoneal (TEP) and transabdominal preperitoneal (TAPP) approach are widely accepted alternatives to open surgery, both providing less postoperative pain, hospital length of stay and early return to work. Classical TEP technique requires three skin incisions for placement of three trocars in the midline or in triangulation. Aim: To describe a technique using only two trocars for laparoscopic total extraperitoneal for inguinal hernia repair. Method: Extraperitoneal access: place two regular trocars on the midline. The $10 \mathrm{~mm}$ is inserted into the subcutaneous in horizontal direction after a transverse infra-umbilical incision and then elevated at $60^{\circ}$ angle. The $5 \mathrm{~mm}$ trocar is inserted at the same level of the pubis with direct vision. Preperitoneal space dissection: introduction $0^{\circ}$ optical laparoscope through the infra-umbilical incision for visualization and preperitoneal dissection; insufflation pressure must be below $12 \mathrm{mmHg}$. Dissection of some anatomical landmarks: pubic bone, arcuate line and inferior epigastric vessels. Exposure of "triangle of pain" and "triangle of doom". Insertion through the $10 \mathrm{~mm}$ trocar polypropylene mesh of $10 \times 15 \mathrm{~cm}$ to cover the hernia sites. Peritoneal sac and the dorsal edge of the mesh are repositioned in order to avoid bending or mesh displacement. It is also important to remember that the drainage is not necessary. Results: The 2-port TEP required less financial costs than usual because it is not necessary an auxiliary surgeon to perform the technique. Trocars, suturing material and wound dressing were spared in comparison to the classical technique. Besides, there were only two incisions, which provides a better plastic result and less postoperative pain. Conclusion. The TEP technique using two trocars is an alternative technique which improves cosmetic and financial outcomes.

\section{Correspondence: \\ Leandro Ryuchi Iuamoto \\ e-mail: leandro.iuamoto@gmail.com \\ Financial source: none \\ Conflicts of interest: none \\ Received for publication: $27 / 11 / 2014$ Accepted for publication: 24/02/2015}

DESCRITORES - Cirurgia laparoscópica. Hérnia inguinal. Tela cirúrgica. Técnica cirúrgica.
RESUMO - Racional: Dentre as correções endoscópicas das hérnias, as abordagens totalmente extraperitoneal (TEP) e transabdominal pré-peritoneal (TAPP) são amplamente aceitas como alternativas à operação aberta, fornecendo menos dor no período pós-operatório, menor tempo de permanência hospitalar e retorno precoce ao trabalho. A técnica TEP clássica requer três incisões na pele para a colocação de três trocárteres na linha média ou em triangulação. Objetivo: Descrever uma técnica utilizando apenas dois trocárteres para hernioplastia laparoscópica totalmente extraperitoneal (TEP). Método: Acesso extraperitoneal: são inseridos dois trocárteres sobre a linha média; um de $10 \mathrm{~mm}$ é inserido no subcutâneo em direção horizontal após incisão infra-umbilical transversal e, em seguida, elevado ao ângulo de $60^{\circ}$; outro de $5 \mathrm{~mm}$ é inserido ao nível do pubis com visão direta. Tempos operatórios: 1) dissecção do espaço preperitoneal: introdução da ótica laparoscópica de $0^{\circ}$ através da incisão infraumbilical para visualização e dissecção pré-peritoneal; pressão de insuflação inferior a 12 $\mathrm{mmHg}$; 2) Dissecção de alguns reparos anatômicos: pubis, linha arqueada e vasos epigástricos inferiores; 3) reconhecimento do "triângulo da dor" e "triângulo do desastre"; 4) Inserção através do trocáter de $10 \mathrm{~mm}$ de tela de polipropileno de $10 \times 15 \mathrm{~cm}$ para cobrir o sitio da hérnia; 5) Reposicionamento do peritônio e da borda dorsal da tela para evitar dobras ou deslocamento da tela. Não é necessária a drenagem. Resultados: Esta técnica foi utilizada em nove pacientes e apresentou bom resultado sem necessidade de um cirurgião auxiliar para executá-la, apenas dois trocáteres, menos material de sutura e de curativos. Além disso, exigiu apenas duas incisões, o que proporcionou melhor resultado estético e menor dor no período pós-operatório. Conclusão. A técnica proposta utilizando dois trocárteres é uma alternativa viável, com melhora dos resultados cosméticos e financeiros.

INTRODUCTION

$\mathrm{T}$ he development of laparoscopic techniques has revolutionized hernia repairs, which is the most common procedure in general surgery worldwide. Its importance goes beyond the individual care, since it has an economical impact on the whole healthcare system. Three billion dollars are spent yearly on the United States to perform an estimate of 750.000 herniorrhaphies ${ }^{12}$. In Brazil, according to Health Department, about 300.000 inguinal hernias are surgically corrected in public and private hospitals per year ${ }^{6}$.

Among endoscopic hernioplasties, totally extraperitoneal (TEP) and transabdominal preperitoneal (TAPP) approach are widely accepted alternatives to open surgery, both providing less postoperative pain, hospital length of stay and early return to work ${ }^{1,4,7,11}$. 
Classical TEP technique requires three skin incisions for placement of three trocars in the midline or in triangulation?. In this study, was introduced a 2-port TEP technique, which would improve cosmetic outcomes and postsurgical recovery.

The aim of this study is to assess and describe a technique using only two trocars for TEP inguinal hernia repair.

\section{METHOD}

\section{Anatomical landmarks and surgical technique}

Preoperative period

Similar to the classical technique, patient is put under general anaesthesia and prophylactic antibiotic therapy. He must urinates before the procedure.

Best positioning is in the supine position with the upper limb along the body on the opposite side of the hernia in the Trendelenburg position. The surgeon must be on the opposite side of the hernia in order to increase and facilitate the work space.

\section{Operative period}

\section{Extraperitoneal access}

For this technique, two regular trocars on the midline are placed, according to the incisions shown in Figure 1 . The $10 \mathrm{~mm}$ trocar is inserted into the subcutaneous in horizontal direction after a transverse infra-umbilical incision and then elevated at $60^{\circ}$ angle. The $5 \mathrm{~mm}$ trocar is inserted at the same level of the pubis with direct vision.

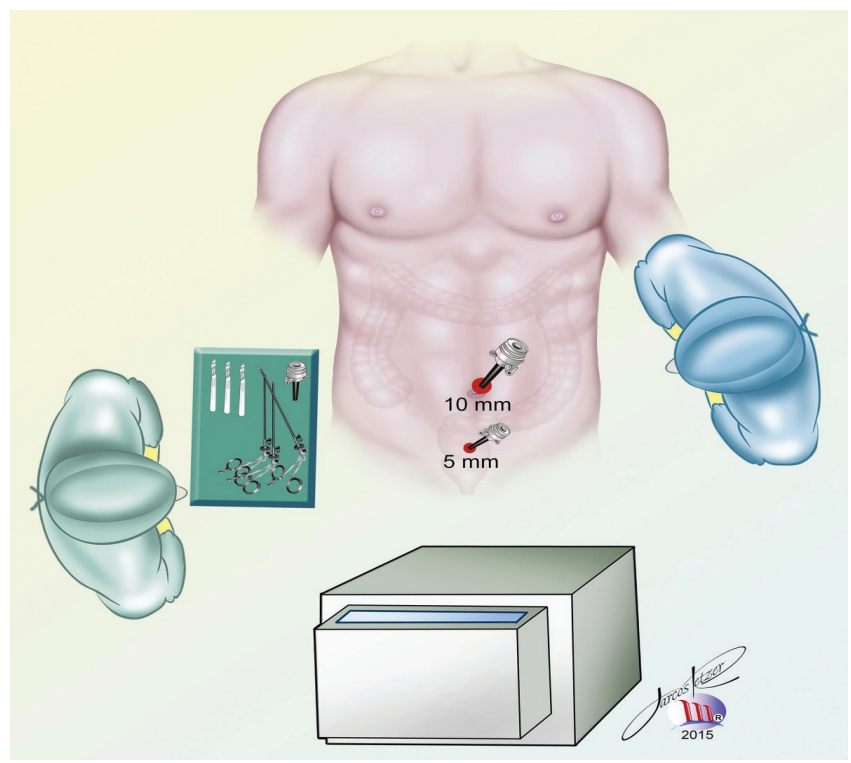

FIGURE 1 - Position of the surgical team (nurse besides the surgical material and main surgeon in front) in the operating room and placement of two regular trocars on the midline

\section{Preperitoneal space dissection}

It is introduced a $0^{\circ}$ optical laparoscope through the infra-umbilical incision for visualization and preperitoneal dissection. Insufflation pressure must stay below $12 \mathrm{mmHg}$. In this meantime, the free hand of the surgeon must be at the abdominal wall to ensure balance.

Surgeon must be aware not to grasp the peritoneal fold itself, to prevent tearing, and not to dissect with diathermy too closely onto the psoas muscle laterally, as this may cause nerve damage.

\section{Medial dissection}

When looking through the laparoscope, it is important to pay attention to some anatomical landmarks such as: 1) pubic bone, 2) arcuate line and 3) inferior epigastric vessels (Figure 2)

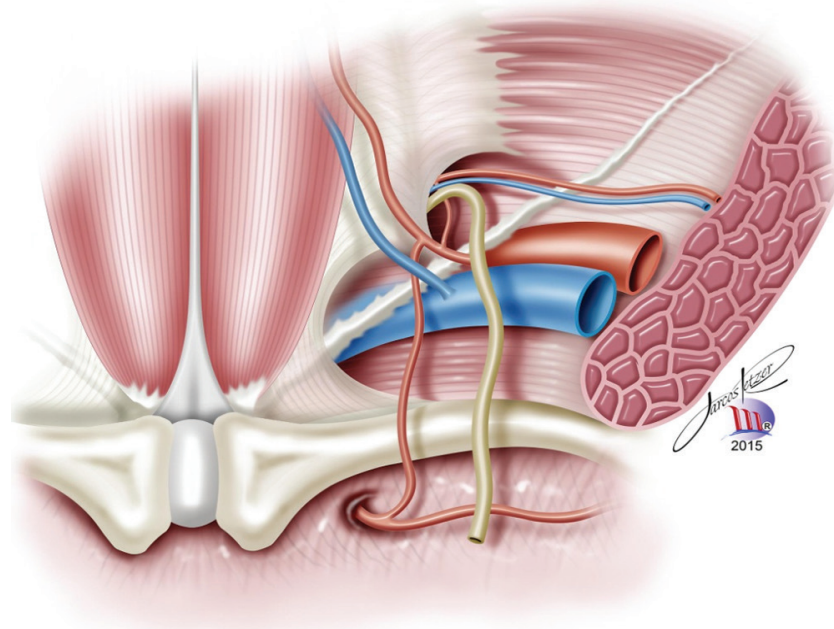

FIGURE 2 - Important anatomical landmarks seen during the procedure: pubic bone, arcuate line and inferior epigastric vessels

\section{Lateral dissection}

Lateral dissection extends to the level of the psoas muscle inferolaterally. The aim is to expose the nerves of the "triangle of pain". Blunt dissection is carefully performed to divide the loose areolar tissue of the lateral space.

An important anatomical landmark is the angle between the inferior epigastric vessels and the arcuate line. Besides, it's necessary to make a safe and adequate dissection when making a small incision in the arcuate line, if it is at a lower level.

\section{Hernia dissection}

The hernia dissection and reduction on spermatic cord structures are performed, besides the reduction of the hernia sac and its reflections. Must pay attention to the "triangle of doom" bounded by the vas deferens (medially), spermatic vessels (laterally), internal inguinal ring (apex) and peritoneum (base)(Figure 3).

When dissecting out an indirect hernia sac, it must be ensured an adequate hemostasis while retracting to avoid small bleeders. This might also prevent seromas and hematomas.

During peritoneal retraction, grasping the ductus deferens may cause fertility problems; overzealous dissection of the cord structures and genital branch of the genitofemoral nerve probably contributes to postoperative neuralgia; dissecting medially the "triangle of doom" is not recommended due to potential injury to the great vessels.

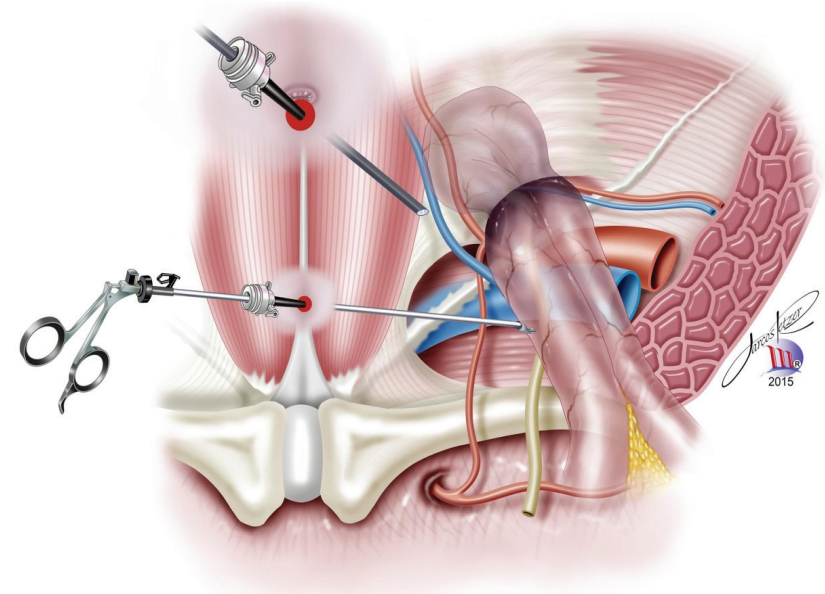

FIGURE 3 - Hernia dissection and important anatomical landmarks: cord structures, internal ring and hernia sac. 


\section{Mesh placement}

The length of polypropylene mesh is calculated and cutted anatomically (at least 10x15 cm). Then, it is inserted through the $10 \mathrm{~mm}$ trocar to cover the hernia sites: inguinal, femoral and obturator.

In bilateral hernia cases, it is easier to put two meshes instead of only large one. Commonly, the mesh is not fixed in order to avoid nerve injury. Only if wide internal ring cases, the mesh is stapled medially in Cooper's ligament in order to prevent neuralgia.

\section{Deflation period}

The hernia sac and the lipoma are placed behind the mesh. Then, inspection for hemostasis in the extraperitoneal space, deflation and closure of skin incisions is performed.

In deflation, the peritoneal sac and the dorsal edge of the mesh are repositioned in order to avoid bending or mesh displacement. It is also important to remember that the drainage is not necessary.

\section{Postoperative period}

The operation described can be made as out-patient surgery, since average discharge is less than $12 \mathrm{~h}$. It brings advantages including organization, material savings ${ }^{10}$ and operative time. Moreover, hospital beds becomes available earlier for those who needs more attention.

\section{Data analysis}

Medical records of 238 patients who underwent elective herniorrhaphy was revised. One senior expert surgeon using the TEP technique realized the surgeries between May 2009 and May 2014. Hernia type, operative time, hospital stay and complications were analyzed.

\section{RESULTS}

Since May 2009 were performed 400 hernia TEP procedures in 238 patients. Among these procedures, there were 16 elective hernioplasty with only two trocars in nine patients. None of them showed any conversion to TAPP or open surgery.

In this series of classical TEP technique, in 229 patients direct hernias counted for 141 (35,25\%), indirect hernia for $254(63,5 \%)$, femoral hernia for 4 (1\%), Spiegel for $1(0,25 \%)$, bilateral for 101 (25,25\%) and recurrent hernia for 48 (12\%). Sixty-four patients had mixed hernia (26,9\%). Average operating time was 45,3 minutes (13-150). There was 16 complications $(4,2 \%)$. Nevertheless, patients who underwent the surgery with two incisions $(n=9)$ had mean operative time of 29,9 minutes (13-45). There were seven direct hernias $(43,7 \%)$, nine indirect $(56,3 \%)$, six bilateral hernias $(66,7 \%)$ and two recurrent hernias $(12,5 \%)$. Three patients $(18,75 \%)$ had mixed hernias. There was no complications reported in these cases and postoperative course was very simple.

\section{DISCUSSION}

Several studies have indicated TEP as the preferred technique, since it avoids intraperitoneal approach and provides even less postoperative morbidity ${ }^{1}$. However, it is a demanding technique ${ }^{14}$ and requires an average of 60-70 procedures per surgeon to achieve a plateau of operative time ${ }^{5}$. Besides the steep learning curve, laparoscopic techniques are not routinely taught to general surgeons and may be challenging due to the limited space especially for those who are unfamiliar with pelvic anatomy $\mathrm{y}^{2,3,8}$.

The 2-port TEP required less financial costs than usual because it is not necessary an auxiliary surgeon to perform the technique. Also, it was spared one trocar, suturing material and wound dressing. Besides, there were only two incisions, which may cause a better plastic result and less postoperative pain.

\section{CONCLUSION}

TEP technique using only two trocars is an alternative technique which improves cosmetic and financial outcomes. Surgeons must be familiarized with different techniques to offer better result to their patients.

\section{ACKNOWLEDGEMENTS}

The authors thank Marcos Retzer for his drawings.

\section{REFERENCES}

1. Bracale U, Melillo P, Pignata G, Di Salvo E, Rovani M, Merola G, et al. Which is the best laparoscopic approach for inguinal hernia repair: TEP or TAPP? A systematic review of the literature with a network meta-analysis. Surg Endosc 2012;26:3355-66.

2. Brassier $D$, Elhadad A. Classic and endoscopic surgical anatomy of the groin. J Chir (Paris) 2007;144:5-10.

3. DaesJ.Theenhancedview-totally extraperitoneal technique for repair of inguinal hernia. Surg Endosc. 2012 Apr;26(4):1187-9.

4. Heniford BT, Park A, Ramshaw BJ, Voeller G. Laparoscopic repair of ventral hernias: nine years' experience with 850 consecutive hernias. Ann Surg. 2003;238(3):391-9.

5. Kukleta JF. TAPP, the logic of hernia repair. Le Jour de Coelio-chir. 2010;76:14-20

6. Meyer A, Berger E, Monteiro Jr. O, Alonso PA, Stavale JN, Gonçalves MPS. Quantitative and qualitative analysis of collagen types in the fascia transversalis of inguinal hernia patients. Arq. Gastroenterol. 2007 Sep;44(3):230-234.

7. Meyer A, BlancP, Balique JG, Kitamura M, Juan RT, Delacoste F, Atger J. Laparoscopictotallyextraperitonealinguinalherniarepair:twenty-sevenserious complications after 4565 consecutive operations. Rev Col Bras Cir. 2013 Jan-Feb;40(1):32-6.

8. Meyer A, Blanc P, Kassir R, Atger J. Laparoscopic Hernia: UmbilicalPubis Length Versus Technical Difficulty. JSLS: Journal of the Society of Laparoendoscopic Surgeons 2014;18(3):e2014.00078.

9. MeyerA, Dulucq JL, MahajnaA. Laparoscopichernia repair:nonfixation mesh is feasibly?. ABCD, arq. bras. cir. dig. 2013 Mar;26(1):27-30.

10. Misra MC, Kumar S, Bansal VK. Total extraperitoneal (TEP) mesh repair of inguinal hernia in the developing world: comparison of low-cost indigenous balloon dissection versus direct telescopic dissection: a prospective randomized controlled study. Surg Endosc 2008;22:1947-58.

11. Pawanindra Lal, Philips $P$, Chander J, Ramteke VK. Is unilateral laparoscopic TEP inguinal hernia repair a job half done? The case for bilateral repair. Surg Endosc 2010;24:1737-45.

12. Rutkow I M. et al. Demographic, classificatory and socioeconomic aspects of hernia repair in the United States.Surg Clin North Am. (1993);73:413-426.

13. Simons MP, Aufenacker T, Bay-Nielsen M, Bouillot JL, Campanelli G, Conze J, de Lange D, Fortelny R, Heikkinen T, Kingsnorth A, Kukleta J, Morales-Conde S, Nordin P, Schumpelick V, Smedberg S, Smietanski M, Weber G, Miserez M. European Hernia Society guidelines on the treatment of inguinal hernia in adult patients. Hernia 2009;13:343403

14. Tse $G H$, de Beaux AC. Laparoscopic hernia repair. Scott Med J 2008:53:34-7. 